University of Nebraska - Lincoln

DigitalCommons@University of Nebraska - Lincoln

\title{
Soil-Crop Dynamic Depth Response Determined from TDR of a Corn Silage Field Compared to EMI Measurements
}

\author{
Bryan L. Woodbury
}

Roger A. Eigenberg

John A. Nienaber

Mindy J. Spiehs

Follow this and additional works at: https://digitalcommons.unl.edu/hruskareports

This Article is brought to you for free and open access by the U.S. Department of Agriculture: Agricultural Research Service, Lincoln, Nebraska at DigitalCommons@University of Nebraska - Lincoln. It has been accepted for inclusion in Roman L. Hruska U.S. Meat Animal Research Center by an authorized administrator of DigitalCommons@University of Nebraska - Lincoln. 


\title{
Soil-Crop Dynamic Depth Response Determined from TDR of a Corn Silage Field Compared to EMI Measurements
}

\author{
Bryan L. Woodbury, Roger A. Eigenberg, John A. Nienaber and Mindy J. Spiehs \\ USDA-ARS, U.S. Meat Animal Research Center, PO Box 166, State Spur 18D, Clay Center, NE 68933 \\ Email: bryan.woodbury@ars.usda.gov
}

\begin{abstract}
Electromagnetic induction (EMI) techniques have been used to monitor bulk seasonal soil-crop apparent electrical conductivity $\left(\mathrm{EC}_{\mathrm{a}}\right)$ dynamics. Interpreting this information can be complicated by changes in the soil profile such as water content or nutrient leaching. Time domain reflectometry (TDR) measures localized soil EC; therefore, TDR can provide clarification to where in the soil profile the EC changes are taking place. The objective of this study was to determine whether surface or deep EC changes were driving the response measured by EMI during the crop season of a field amended with animal manure. Results indicate that seasonal soil-crop EC dynamics measured by EMI are primarily driven by surface $(<0.2 \mathrm{~m})$ changes as opposed to deeper $(>0.9 \mathrm{~m})$ changes. These changes appear to be the result of surface ionic dynamics caused by crop-soil interactions and not soil volumetric water content $\left(\theta_{\mathrm{v}}\right)$, since no significant correlations were detected between $\theta_{\mathrm{v}}$ and $\mathrm{EC}_{\mathrm{a}}$ for any treatment, depth or dipole orientation. These findings are consistent with others who reported the EMI signal was driven primarily by changes in nitrate concentration and not by soil water content. The results of this study clarify our understanding of the soil dynamics that drive the $\mathrm{EC}_{\mathrm{a}}$ response of a manure amended field. The ability to non-intrusively measure nutrient mineralization and crop uptake provides researchers with a powerful tool for understanding soil-crop interactions. Understanding the soil-crop dynamic will facilitate development of management practices for amending soil with manure while protecting the environment from unintended contamination.
\end{abstract}

\section{Introduction}

The U.S. Environmental Protection Agency (USEPA) requires that concentrated animal feeding operations (CAFOs) develop nutrient management plans (NMPs) to dispose of the animal manure generated during production (USEPA, 2003). Much of this manure is applied to the soil as a fertilizer amendment for the production of crops. When applied at agronomic rates, manure can be a valuable fertilizer, as well as an excellent amendment to improve overall soil quality (Dordas et al., 2008; Haynes and Naidu, 1998; Hepperly et al., 2009; Nyiraneza et al., 2009). The transportation, storage, and treatment of manure are costly, and therefore most of the manure is applied to fields near the CAFO. As a result, any over-application or unused mineralized nutrients can be a risk to the environment if moved off-site. This risk can be realized with nutrients, endocrine disrupting compounds, pharmaceuticals, organics and pathogens as contaminants of soil, surface and groundwater resources (Chee-Sanford et al., 2009; Hanselman, T.A. et al., 2003; Khan et al.,
2007; McDowell and Sharpley, 2002). Therefore, the effective use of manure as a soil amendment needs to be improved to ensure adequate protection of the environment and human health.

The key to applying animal waste as a fertilizer amendment without contaminating the surrounding environment is to apply only the amount that will be mineralized and utilized by the crop (Dordas et al., 2008; Ferguson et al., 2005; Gilley et al., 2008; Wortmann and Walters, 2006). Although this concept is simple, it is very difficult to put into practice. Manure application and management is complicated by the inability to accurately estimate the amount of nutrients mineralized during the growing season, to evenly apply the waste across the field, and predict environmental conditions as well as compensate for inherent soil spatial variability (Hepperly et al., 2009; Nyiraneza et al., 2009; Watts et al., 2007).

Researchers have begun to develop predictive relationships that quantify key soil factors affecting nutrient mineralization of manure (Griffin et al., 2002, 2008; Hubbard et al., 2007; Honeycutt et al., 2005; 
Journal of Environmental and Engineering Geophysics

Watts et al., 2007). These studies estimate how temperature, soil water status, soil type and manure source affects the amount of nitrogen mineralized in a typical growing season. Additionally, these studies evaluated the effect of geographical region on nitrogen mineralization. These predictive relationships should improve judicious use of animal manure as a fertilizer; however, these relationships will not be able to account for short-term, soil-crop dynamics driven by local climatic conditions or inherent soil variability commonly found within most agricultural fields. Combining these predictive relationships with innovative subsurface measures of mineralization and crop uptake should result in improved management of land applied manure and reduce risk to the environment.

Much work has been done to develop electromagnetic induction (EMI) sensing techniques that measure field-scale spatial variability and the impact of management on soil EC (Eigenberg et al., 2003, 2008; Johnson et al., 2005; Woodbury et al., 2009). Work by Robinson et al. (2008) evaluated the appropriateness of using EMI technology to understand the connection of soil physical/chemical properties and vegetation patterns at the watershed scale. They concluded there was a strong coupling between the EMI signal (in response to soil properties) and vegetation community patterns that were not evident using traditional soil survey techniques. Also, Martinez et al. (2009) used EMI to improve the spatial characterization of soil organic carbon. They found $\mathrm{EC}_{\mathrm{a}}$ surveys can provide inexpensive and useful information to evaluate the quantitative spatial characterization of soil organic carbon. They were able to clarify differences in soil properties and explain much of the soil organic carbon spatial variability resulting from management by using the $\mathrm{EC}_{\mathrm{a}}$ survey data. Additional work by Cockx et al. (2009) used EMI data combined with artificial neural network to extract information on the topsoil clay content of an agricultural soil. By combining the EMI data with artificial neural network analysis, they increased the information available on the characteristic of topsoil. They also concluded that proximally sensed soil data, like EMI, can be a useful tool for optimizing the prediction of textural information.

Eigenberg et al. (2002, 2003) have developed methods for monitoring $\mathrm{N}$ dynamics of animal manure amended soils using EMI. They found the profile weighted $\mathrm{EC}_{\mathrm{a}}$ values were highly correlated with soil $\mathrm{NO}_{3}-\mathrm{N}$ in the surface $0-23 \mathrm{~cm}$ and $23-46 \mathrm{~cm}$ soil layers throughout the growing season. Eigenberg et al. (2006) also measured soil-crop dynamics on a corn silage plot designed to compare long-term additions of animal manure or commercial fertilizer on yield, and found that seasonal nitrogen dynamics were largely responsible for the observed seasonal changes in $\mathrm{EC}_{\mathrm{a}}$. However, this technique lacked the ability to distinguish where in the soil profile the seasonal change in $\mathrm{EC}_{\mathrm{a}}$ was taking place.

Time domain reflectometry (TDR) has been used as a means for independent determination of volumetric water content $(\theta \mathrm{v})$ and bulk soil electrical conductivity (EC $\mathrm{EDR}_{\mathrm{TDR}}$ ) (Dalton, 1992; Dalton et al., 1984). More recently, TDR has been adapted to indirectly measure soil solution EC, and researchers have attempted to develop predictive equations for estimating soil nitrate levels (Das et al., 1999; Nissen et al., 1998). TDR has the ability to monitor $\mathrm{EC}_{\mathrm{TDR}}$ in a zone surrounding the probe and can be precisely located in the soil profile. Comparing these two different and independent measures of soil EC throughout a crop season should provide insight to where in the soil profile the soil-crop EC dynamic is taking place. Additional information may be provided on the effect water content has on $\mathrm{EC}_{\mathrm{a}}$ dynamic as measured by EMI.

Clarifying the depth of the seasonal soil-crop dynamic measured by EMI will enable researchers to use EMI as a tool for investigating manure utilization. These investigations will aid researchers in developing management practices that minimize environmental consequences of land application. The objectives of this study were to: 1) determine whether surface or deep EC changes were driving the EMI response; and 2) evaluate the influence of soil volumetric water content $\left(\theta_{\mathrm{v}}\right)$ on the measured EMI response of a corn silage field fertilized with animal manure.

\section{Materials and Methods}

Data for this investigation were collected from two separate experiments on two different field sites at the U.S. Meat Animal Research Center, Clay Center, Nebraska. The field sites were within $500 \mathrm{~m}$ of each other and were comprised of Crete silt loam soil series, located on a 0 to 1 percent slope (fine, smectitic, mesic Pachic Argiustolls). Both fields were irrigated using center pivot systems to supplement precipitation to achieve a total water application of approximately $4 \mathrm{~cm}$ per week. Experiment 1 and 2 treatment plots were 6-m wide by $245-\mathrm{m}$ long. Each treatment plot contained eight corn rows.

\section{Field Sites and Experimental Design}

Details of the field site used during Experiment 1 can be found in Ferguson et al. (2005). Only a portion of the field site was used to accomplish the objectives of this investigation. The experimental design for Experiment 1 was a randomized block design with main treatments of cover $(\mathrm{Cv})$ and no-cover $(\mathrm{NCv})$ crop. The sub-treatments were commercial fertilizer (NK), manure 
Woodbury et al.: Dynamic Depth Response from TDR

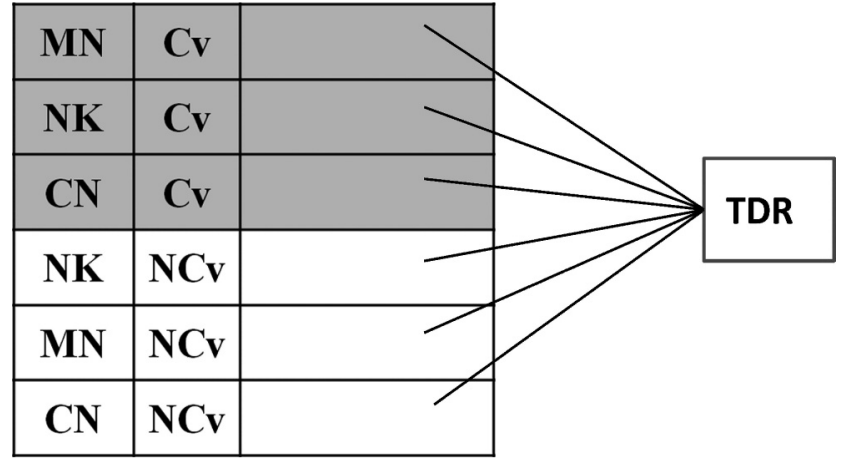

Figure 1. Illustration of setup for Experiment 1. Placement of the TDR probes were vertical from 5 to $20 \mathrm{~cm}$. Note the shaded sections indicate treatments with a cover-crop main treatment.

$(\mathrm{MN})$, and compost $(\mathrm{CN})$ to meet the crop's nitrogen requirement (Fig. 1).

The field site used for Experiment 2 was established to investigate the effects the timing of cover-crop destruction on a corn silage crop. Again, only a portion of this field site was used to accomplish the objectives of Experiment 2. The Experiment 2 design was a randomized block design with main treatments of $\mathrm{Cv}$ and $\mathrm{NCv}$ crop (Fig. 2). The sub-treatments selected for this investigation were manure and commercial fertilizer (MN and NK, respectively) to meet the $\mathrm{N}$ requirements of the corn silage crop. The reason for selecting these treatments was to focus the investigation on high $\mathrm{N}$ rate from manure.

Beef cattle manure or compost amendments were applied early in the spring using a field spreader. The winter cover-crop was destroyed using a non-selective herbicide, prior to tilling with a double off-set tandem disk following amendment application. Plots were planted near the end of April (Table 1). Surface TDR probes and wires were removed to facilitate agronomic events such as fertilizer application, harvesting and cover-crop planting. Probes were reinstalled following these operations. A more detailed listing of specific agronomic events for Experiment 1 and 2 are included in Table 1 .

\section{$\underline{\text { TDR and EMI Measurements }}$}

Volumetric water content $\left(\theta_{\mathrm{v}}\right)$ from the TDR waveform was determined using the Topp equation (Topp et al., 1980), and $\mathrm{EC}_{\mathrm{TDR}}$ was measured using the Giese and Tiemann theory for electromagnetic waves (Giese and Tiemannn, 1975). Cell constants and temperature corrections for each probe were determined using laboratory calibrations. Probes were constructed with a three-rod design using 3.2-mm diameter stainless steel rods. A 30-mm spacing was used between rods, and

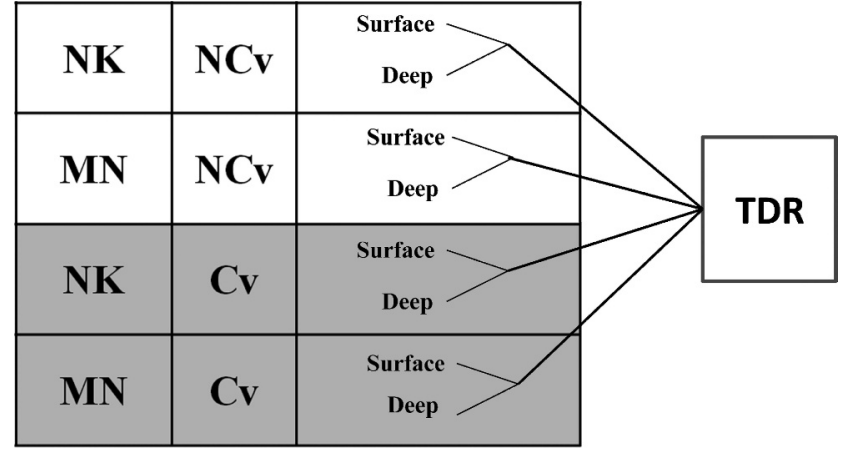

Figure 2. Illustration of setup for Experiment 2. Orientation and placement of the surface TDR probes were vertical from 0.055 to $0.2 \mathrm{~m}$, and the orientation and placement of the deep TDR probes were horizontal at approximately $0.9 \mathrm{~m}$. Note the shaded sections indicate treatments with a cover-crop treatment.

the length of the exposed rods was $12.5 \mathrm{~cm}$. Cable runs greater than $15 \mathrm{~m}$ utilized low impedance RG-8 cable, while cable runs less than $15 \mathrm{~m}$ utilized RG-58 cable. All equipment, cables, and connectors were $50 \mathrm{ohm}$ impedance. Guide blocks were used to maintain parallel probe orientation while the probe was inserted into the soil.

Field $\mathrm{EC}_{\mathrm{TDR}}$ and $\mathrm{EC}_{\mathrm{a}}$ data were collected using both TDR and EMI, respectively, from approximately the middle of April until the middle of October for the two growing seasons. Time domain reflectometry data were collected every $15 \mathrm{~min}$ and averaged every hour. Surface probes were placed vertically in the corn row near the center of $\mathrm{MN}-\mathrm{Cv}, \mathrm{NK}-\mathrm{Cv}, \mathrm{CN}-\mathrm{Cv}, \mathrm{NK}-\mathrm{NCv}$, $\mathrm{MN}-\mathrm{NCv}$, and $\mathrm{CN}-\mathrm{NCv}$ treatment for Experiment 1 (Fig. 1). This orientation and depth was selected to evaluate the biologically active upper $5-$ to $20-\mathrm{cm}$ depth (surface). Type $\mathrm{T}$ thermocouples were installed at each location at a depth of $15 \mathrm{~cm}$ to record soil temperatures for correction of the EC.

Surface probes were placed vertically in the corn row near the center of $\mathrm{NK}-\mathrm{NCv}, \mathrm{MN}-\mathrm{NCv}, \mathrm{NK}-\mathrm{Cv}$, $\mathrm{MN}-\mathrm{Cv}$ for Experiment 2 (Fig. 2). The deep TDR probes $(0.9 \mathrm{~m})$ were placed in the horizontal position in the same row. When surface probes were removed to facilitate an agronomic event, they were re-inserted in an undisturbed location as close as possible to directly above the deep probes.

A DualEM-1S ${ }^{1}$ was used to collect $\mathrm{EC}_{\mathrm{a}}$ values in both the perpendicular (PRP) and horizontal co-planer (HCP) orientations on approximately a weekly basis. The cumulative response profile function for the PRP

\footnotetext{
${ }^{1}$ Mention of trade names or commercial products in this article is solely for the purpose of providing specific information and does not imply recommendation or endorsement by the U.S. Department of Agriculture.
} 
Table 1. Day of year for specific agronomic events for Experiment 1 and 2. Year, month and day are shown in parenthesis for the events.

\begin{tabular}{ccccccccc}
\hline \hline Experiment & $\begin{array}{c}\text { Cover-crop } \\
\text { killed }\end{array}$ & $\begin{array}{c}\text { Manure compost } \\
\text { applied }\end{array}$ & $\begin{array}{c}\text { Field } \\
\text { planted }\end{array}$ & $\begin{array}{c}\text { Anhydrous } \\
\text { ammonia applied }\end{array}$ & $\begin{array}{c}\text { Corn } \\
\text { 30 cm tall }\end{array}$ & Silk & $\begin{array}{c}\text { Cover } \\
\text { Harvest }\end{array}$ & planted \\
\hline $1(2002)$ & $108(4 / 18)$ & $110(4 / 20)$ & $112(4 / 22)$ & $167(6 / 16)$ & $177(6 / 27)$ & $206(7 / 25)$ & $250(9 / 7)$ & $269(9 / 25)$ \\
$2(2006)$ & $101(4 / 11)$ & $105(4 / 15)$ & $115(4 / 25)$ & $166(6 / 15)$ & $170(6 / 19)$ & $203(7 / 22)$ & $242(8 / 30)$ & $261(9 / 18)$ \\
\hline
\end{tabular}

orientation is:

$$
\mathrm{R}_{\mathrm{cPRP}}=2 \mathrm{~s} /\left(4 \mathrm{~s}^{2}+1\right)^{0.5},
$$

where $R_{c P R P}$ is the cumulative response for the PRP orientation and $\mathrm{s}$ is depth. This results in a PRP cumulative response for the $0-0.2 \mathrm{~m}$ depth of $37.1 \%$ and $4.5 \%$ for the $0.8-1.0 \mathrm{~m}$ depth. The cumulative response profile function for the HCP orientation is:

$$
\mathrm{R}_{\mathrm{cHCP}}=1-1 /\left(4 \mathrm{~s}^{2}+1\right)^{0.5},
$$

where $\mathrm{R}_{\mathrm{cHCP}}$ is the cumulative response for the HCP orientation and $s$ is depth. This results in a HCP cumulative response for the $0-0.2 \mathrm{~m}$ depth of $7.1 \%$ and $8.0 \%$ for the $0.8-1.0 \mathrm{~m}$ depth. The PRP cumulative response near the surface $(0-0.2 \mathrm{~m})$ is much greater than at depth $(0.8-1.0 \mathrm{~m})$; the $\mathrm{HCP}$ cumulative response is marginal both near surface $(0-0.2 \mathrm{~m})$ and deeper $(0.8-$ $1.0 \mathrm{~m}$ ). Hence, the anticipated responses to near surface soil conductivity variations will predominately occur with the PRP signal. Eigenberg et al. (2006) give a detailed discussion of the depth response profile of the DualEM used for this study. These data, combined with GPS coordinates, were collected at a rate of approximately 5 per second. A $30-\mathrm{m}$ section $(15 \mathrm{~m}$ on either side of the probe) of $\mathrm{EC}_{\mathrm{a}}$ values near the TDR probes were averaged to limit plot soil spatial variability. Also, $\mathrm{EC}_{\mathrm{a}}$ values affected by the buried TDR probes and cables were removed from this average. These values were easily identified by inspection because of the effect of metals on the EMI signal.

Soil profile temperatures were monitored using thermocouple temperature probes buried at the field site of Experiment 2. These temperatures were used to correct the $\mathrm{EC}_{\mathrm{a}}$ values using a procedure described by Eigenberg et al. (2006). Probes were installed at 5 and $15 \mathrm{~cm}$ beneath the surface, then at $30-\mathrm{cm}$ intervals to $135 \mathrm{~cm}$, and at $60-\mathrm{cm}$ intervals to $315 \mathrm{~cm}$. The temperatures were logged on 1-h intervals (Campbell Scientific CR10X with AM16/32 multiplexer, Campbell Scientific, Logan, UT). The soil temperatures for correcting the EMI readings were computed based on the contribution to the response function at each probe depth through the profile. These data were used to establish a temperature correction for each survey date following the approach of McKenzie et al. (1989).

\section{Statistical Analysis}

Each data set from Experiments 1 and 2 were treated as a repeated measure. The unit of observation for this study was TDR probe site with day as the repeated measure. Each time series data set was tested for autocorrelation using the Durbin-Watson statistic in PROC REG of SAS. The $1^{\text {st }}$ order autocorrelation values are listed in Table 2. There was some dependence between successive time series points; however, the independence between points was considered sufficient for Pearson correlation analysis. Pearson correlation coefficients were calculated between PRP, HCP, EC and surface/deep $\mathrm{EC}_{\mathrm{TDR}}$ values using PROC REG of SAS. Test for significance for all correlations was set at $P \leq 0.05$.

\section{Results}

\section{Experiment 1}

Pearson correlation coefficients from Experiment 1 between $\mathrm{EC}_{\mathrm{TDR}}$ and PRP $\mathrm{EC}_{\mathrm{a}}$ for EMI survey dates for each treatment are included in Table 3. Significant $(P<0.05)$ positive correlations were measured for all treatment combinations except $\mathrm{NK}-\mathrm{NCV}$ treatment. Strongest positive correlations were for $\mathrm{CN}-\mathrm{Cv}(0.831)$ and $\mathrm{MN}-\mathrm{Cv}$ (0.829) (Table 3). Each of these treatments had p-values less than 0.0001. Interestingly, no-cover crop EC values as measured by TDR and EMI were greater than cover treatments throughout most of the growing season for Experiment 1 (Fig. 3). The fall planted cover-crop utilized nutrients that were mineralized after harvest and removed those soluble nutrients from the soil solution. Ferguson et al. (2005) also concluded that fall cover-crop reduced nutrient leaching, particularly $\mathrm{N}$, by incorporating the nutrients into plant matter. In the spring, this cover-crop was incorporated prior to planting. Micro-organisms removed nutrients from the soil solution to mineralize incorporated cover-crop, thereby lowering the solution EC. This pattern observed during the spring was similar to the pattern described by Eigenberg et al. (2006). 
Table 2. First order autocorrelation values for each time series EC measure by treatment, experiment, method of measure and depth/orientation. Where commercial fertilizer (NK), manure (MN) and compost (CN) was applied at the agronomic nitrogen rate for a corn silage crop. Each fertilizer treatment was with $(\mathrm{Cv})$ or without (NCv) a winter cover-crop.

\begin{tabular}{|c|c|c|c|c|}
\hline Treatment & Exp. & $\begin{array}{c}\text { EC } \\
\text { method }\end{array}$ & $\begin{array}{c}\text { Depth/ } \\
\text { Orientation }\end{array}$ & $\begin{array}{c}\text { First order } \\
\text { autocorrelation }\end{array}$ \\
\hline $\mathrm{NK}-\mathrm{NCV}$ & 1 & TDR & Surface $^{1}$ & 0.189 \\
\hline $\mathrm{NK}-\mathrm{NCV}$ & 1 & EMI & $\mathrm{PRP}^{2}$ & -0.167 \\
\hline $\mathrm{MN}-\mathrm{NCV}$ & 1 & TDR & Surface & 0.211 \\
\hline $\mathrm{MN}-\mathrm{NCV}$ & 1 & EMI & PRP & -0.051 \\
\hline $\mathrm{CN}-\mathrm{NCV}$ & 1 & TDR & Surface & 0.231 \\
\hline $\mathrm{CN}-\mathrm{NCV}$ & 1 & EMI & PRP & 0.029 \\
\hline $\mathrm{NK}-\mathrm{Cv}$ & 1 & TDR & Surface & -0.047 \\
\hline $\mathrm{NK}-\mathrm{CV}$ & 1 & EMI & PRP & -0.185 \\
\hline $\mathrm{MN}-\mathrm{Cv}$ & 1 & TDR & Surface & 0.159 \\
\hline $\mathrm{MN}-\mathrm{Cv}$ & 1 & EMI & PRP & -0.127 \\
\hline $\mathrm{CN}-\mathrm{Cv}$ & 1 & TDR & Surface & 0.171 \\
\hline $\mathrm{CN}-\mathrm{Cv}$ & 1 & EMI & PRP & 0.000 \\
\hline $\mathrm{NK}-\mathrm{NCV}$ & 2 & TDR & Surface & -0.094 \\
\hline $\mathrm{NK}-\mathrm{NCV}$ & 2 & TDR & Deep $^{3}$ & -0.036 \\
\hline $\mathrm{NK}-\mathrm{NCV}$ & 2 & EMI & PRP & -0.352 \\
\hline $\mathrm{NK}-\mathrm{NCV}$ & 2 & EMI & $\mathrm{HCP}^{4}$ & -0.391 \\
\hline $\mathrm{MN}-\mathrm{NCV}$ & 2 & TDR & Surface & -0.163 \\
\hline $\mathrm{MN}-\mathrm{NCV}$ & 2 & TDR & Deep & -0.453 \\
\hline $\mathrm{MN}-\mathrm{NCV}$ & 2 & EMI & PRP & -0.184 \\
\hline $\mathrm{MN}-\mathrm{NCV}$ & 2 & EMI & $\mathrm{HCP}$ & -0.114 \\
\hline $\mathrm{NK}-\mathrm{Cv}$ & 2 & TDR & Surface & -0.658 \\
\hline $\mathrm{NK}-\mathrm{Cv}$ & 2 & TDR & Deep & -0.185 \\
\hline $\mathrm{NK}-\mathrm{Cv}$ & 2 & EMI & PRP & -0.330 \\
\hline $\mathrm{NK}-\mathrm{Cv}$ & 2 & EMI & $\mathrm{HCP}$ & -0.119 \\
\hline $\mathrm{MN}-\mathrm{Cv}$ & 2 & TDR & Surface & -0.320 \\
\hline $\mathrm{MN}-\mathrm{Cv}$ & 2 & TDR & Deep & -0.137 \\
\hline $\mathrm{MN}-\mathrm{Cv}$ & 2 & EMI & PRP & -0.119 \\
\hline $\mathrm{MN}-\mathrm{Cv}$ & 2 & EMI & $\mathrm{HCP}$ & -0.330 \\
\hline
\end{tabular}

${ }^{1}$ Surface is the EC value measured by time-domain reflectometry with the probe oriented in the vertical direction measuring the surface 5-20 cm depth.

${ }^{2}$ PRP is the perpendicular coil orientation of the DualEM-1S.

${ }^{3}$ Deep is the EC value measured by time-domain reflectometry with the probe oriented in the horizontal direction measuring at a $0.9 \mathrm{~m}$ depth.

${ }^{4} \mathrm{HCP}$ is the horizontal co-planar coil orientation of the DaulEM-1S.

There was a significant $(P<0.05)$ positive correlation between $\mathrm{EC}_{\mathrm{TDR}}$ and $\mathrm{PRP} \mathrm{EC}_{\mathrm{a}}$ values for the $\mathrm{NK}-\mathrm{Cv}$ treatment in Experiment 1 (Table 3). However, there was a negative correlation between the $\mathrm{EC}_{\mathrm{TDR}}$ and PRP $\mathrm{EC}_{\mathrm{a}}$ values for the $\mathrm{NK}-\mathrm{NCv}$ treatment
Table 3. Experiment 1 correlation coefficients of EC values for plots fertilized with compost $(\mathrm{CN})$, manure (MH) and commercial fertilizer (NK) to meet the nitrogen needs of a corn silage field with a winter cover-crop (Cv) and without a winter cover-crop ( $\mathrm{NCv}$ ).

\begin{tabular}{lcr}
\hline \hline \multicolumn{3}{c}{ Correlation coefficients } \\
\hline Treatment & Surface $^{1}$ vs. PRP $^{\mathbf{2}}$ & \multicolumn{1}{c}{$\boldsymbol{P}$ value } \\
\hline $\mathrm{CN} \mathrm{Cv}$ & 0.831 & $<0.0001$ \\
$\mathrm{CN} \mathrm{NCv}$ & 0.714 & 0.0013 \\
$\mathrm{MN} \mathrm{Cv}$ & 0.829 & $<0.0001$ \\
$\mathrm{MN} \mathrm{NCv}$ & 0.536 & 0.0264 \\
$\mathrm{NK} \mathrm{Cv}$ & 0.782 & 0.0350 \\
$\mathrm{NK} \mathrm{NCv}$ & -0.482 & 0.0726 \\
\hline
\end{tabular}

${ }^{1}$ Surface is the EC value measured by time-domain reflectometry with the probe oriented in the vertical direction measuring the surface 5-20 cm depth.

${ }^{2}$ PRP is the perpendicular coil orientation of the DualEM-1S.

(Table 3). Both $\mathrm{EC}_{\mathrm{TDR}}$ and PRP $\mathrm{EC}_{\mathrm{a}}$ values for the $\mathrm{NK}-\mathrm{Cv}$ and $\mathrm{NK}-\mathrm{NCV}$ treatments followed similar trends until the addition of nitrogen fertilizer (day 167), when the $\mathrm{EC}_{\mathrm{TDR}}$ for $\mathrm{NK}-\mathrm{NCv}$ increased while PRP EC $\mathrm{E}_{\mathrm{a}}$ for NK-NCv continued to decrease (Fig. 3). This elevated $\mathrm{EC}_{\mathrm{TDR}}$ continued for the remainder of the sampling period until after the cover-crop emerged and began utilizing residual nitrogen. The effect of fertilizer addition on $\mathrm{EC}_{\mathrm{TDR}}$ was probably the result of its close proximity to the probe and volume of soil measured. Fertilizer addition was in a narrow band and had a measurable impact because the volume of soil measured by TDR was relatively small compared to PRP $\mathrm{EC}_{\mathrm{a}}$. The larger surface area used to calculate a PRP $E_{a}$ value diluted the effect of the narrow concentrated band. Although we have no soil test data for verification, persistence of elevated $\mathrm{EC}_{\mathrm{TDR}}$ values could be a result of drought conditions and lower than expected yield, which used less nitrogen than expected during Experiment 1.

\section{Experiment 2}

There were significant $(P \leq 0.05)$ correlations between the surface $\mathrm{EC}_{\mathrm{TDR}}$ and the PRP EC $\mathrm{C}_{\mathrm{a}}$ treatments with and without winter cover-crop for Experiment 2 (Table 4 and Fig. 4). Also, there were significant correlations between surface $\mathrm{EC}_{\mathrm{TDR}}$ and $\mathrm{HCP} \mathrm{EC}_{\mathrm{a}}$ for the $\mathrm{MN}-\mathrm{NCv}$ and $\mathrm{NK}-\mathrm{NCv}$ treatments, but no significant correlations between surface $\mathrm{EC}_{\mathrm{TDR}}$ and $\mathrm{HCP} \mathrm{EC}_{\mathrm{a}}$ were detected for the $\mathrm{Cv}$ treatments. Even though correlations for these treatments were not significant, there were positive correlations between surface $\mathrm{EC}_{\mathrm{TDR}}$ and $\mathrm{EC}_{\mathrm{a}}$. Surface driven EC fluctuations impact the 
Journal of Environmental and Engineering Geophysics
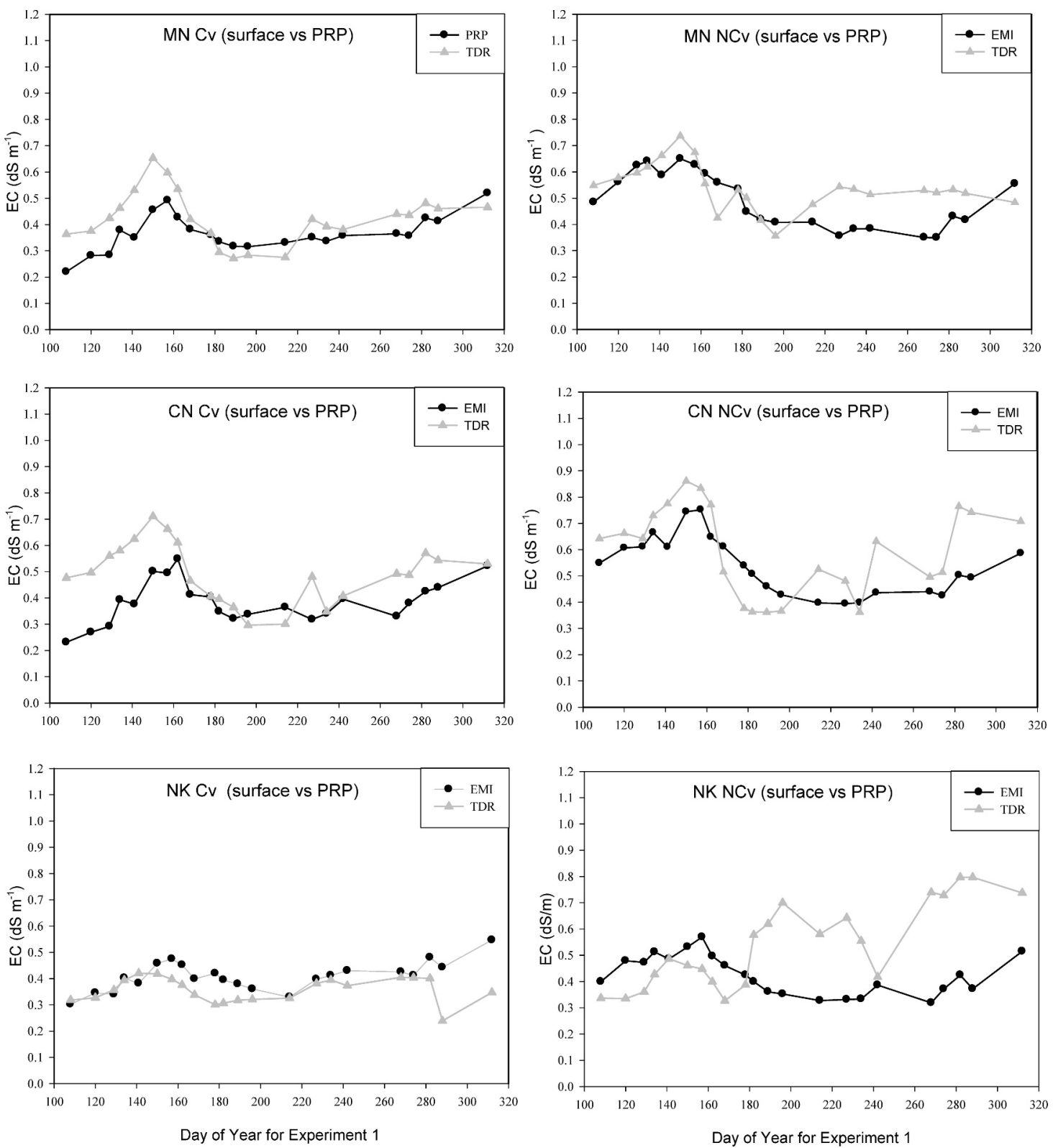

Figure 3. Apparent soil electrical conductivity as measured by electromagnetic induction (EMI) and surface soil electrical conductivity as measured by time-domain reflectometry (TDR) for manure (MN), compost (CN) and commercial fertilizer (NK) at the nitrogen rate for a corn silage crop, with a winter cover-crop (Cv) and no-cover crop (NCv) treatment for Experiment 1. Note PRP and HCP refer to the perdendicular and horizontal co-planar coil orientation, respectively, of the DualEM-1S.

values measured by both PRP and HCP orientations. The extent these values are influenced is dependent on the orientation depth response curves and the resulting centroid of measure (Eigenberg et al., 2006). The HCP orientation is less affected by surface dynamics than the perpendicular orientation and has a deeper centroid of measure than the PRP orientation. Therefore, seasonal changes measured by the near-surface TDR probe would not be expected to correlate as strongly for
HCP compared with PRP values. This finding is consistent with those of Eigenberg et al. (2003) when they reported the EMI signal change was driven primarily by nitrate concentration changes in the surface soil profile and not by soil water content.

There were no significant correlations between the deep $\mathrm{EC}_{\mathrm{TDR}}$ values and $\mathrm{EC}_{\mathrm{a}}$ for either orientation for all Experiment 2 treatments (Table 4). The lack of correlation was primarily driven by the relative stability of 
Table 4. Experiment 2 correlation coefficients of EC values for plots fertilized with commercial fertilizer (NK) and manure $(\mathrm{MH})$ to meet the nitrogen needs of a corn silage field with a winter cover-crop (Cv) and without a winter cover$\operatorname{crop}(\mathrm{NCv})$.

\begin{tabular}{|c|c|c|c|c|c|c|c|c|}
\hline Treatment & Surface $^{1}$ vs. PRP ${ }^{2}$ & $P$ value & Deep $^{3}$ vs. PRP & $P$ value & Surface vs. $\mathrm{HCP}^{4}$ & $P$ value & Deep vs. HCP & $P$ value \\
\hline \multicolumn{9}{|c|}{$\mathrm{EC}_{\mathrm{TDR}}$ vs. $\mathrm{EC}_{\mathrm{a}}$ Correlation Coefficients } \\
\hline $\mathrm{NK} \mathrm{NCv}$ & 0.803 & 0.0091 & -0.221 & 0.567 & 0.672 & 0.047 & -0.346 & 0.362 \\
\hline $\mathrm{MN} \mathrm{NCv}$ & 0.860 & 0.003 & 0.292 & 0.447 & 0.844 & 0.004 & -0.009 & 0.982 \\
\hline $\mathrm{NK} \mathrm{Cv}$ & 0.753 & 0.0191 & 0.174 & 0.654 & 0.602 & 0.086 & 0.409 & 0.274 \\
\hline $\mathrm{MN} \mathrm{Cv}$ & 0.827 & 0.0059 & 0.191 & 0.623 & 0.542 & 0.131 & 0.464 & 0.208 \\
\hline \multicolumn{9}{|c|}{ Volumetric Water Content vs. $\mathrm{EC}_{\mathrm{a}}$ Correlation Coefficients } \\
\hline $\mathrm{NK} \mathrm{NCv}$ & 0.328 & 0.557 & -0.084 & 0.262 & 0.281 & 0.272 & -0.182 & 0.128 \\
\hline $\mathrm{MN} \mathrm{NCV}$ & 0.527 & 0.145 & -0.150 & 0.701 & 0.522 & 0.150 & -0.358 & 0.345 \\
\hline NK Cv & -0.265 & 0.491 & 0.368 & 0.329 & -0.031 & 0.937 & 0.567 & 0.111 \\
\hline $\mathrm{MN} \mathrm{Cv}$ & -0.229 & 0.554 & 0.518 & 0.153 & -0.063 & 0.872 & 0.626 & 0.071 \\
\hline \multicolumn{9}{|c|}{$\begin{array}{l}{ }^{1} \text { Surface is the EC value measured by time-domain reflectometry with the probe oriented in the vertical direction measuring the } \\
\text { surface } 5-20 \mathrm{~cm} \text { depth. } \\
2 \text { PRP is the perpendicular coil orientation of the DualEM-1S. } \\
\text { Peep is the EC value measured by time-domain reflectometry with the probe oriented in the horizontal coplanar direction } \\
\text { measuring at a } 0.9 \mathrm{~m} \text { depth. }\end{array}$} \\
\hline
\end{tabular}

the $\mathrm{EC}_{\mathrm{TDR}}$ values at the $0.9-\mathrm{m}$ depth (Fig. 5), which exhibited little seasonal fluctuations. The EC at $0.9-\mathrm{m}$ depth was probably buffered by calcareous loess located at that depth that limited any fluctuations created by the growing crop. It should be noted that the $\mathrm{EC}_{\mathrm{TDR}}$ values were higher than the $\mathrm{EC}_{\mathrm{a}}$ for all treatments and sampling times illustrating the effect of depth averaging by the EMI system and the relative point measurements made by the TDR system (Fig. 5).

Another interesting observation was the limited change in $\mathrm{EC}_{\mathrm{TDR}}$ values at the $0.9-\mathrm{m}$ depth, particularly following the addition of anhydrous ammonia on day 166. This would indicate limited deep leaching of the nitrogen either in the ammonium or nitrate forms. Generally, when anhydrous ammonia is injected into soil it immediately reacts with the soil water and is converted to ammonium. These ammonium ions can be bound on soil cation exchange sites with the soil water until it is microbiologically converted to nitrate-nitrogen. Once converted, the corn silage crop would utilize this nitrate for growth. The accelerated extraction of nitrate-nitrogen from the soil by the crop upon reaching the $0.3-\mathrm{m}$ height would limit the opportunity for leaching to be measured by the TDR probe at the 0.9$\mathrm{m}$ depth. Also, limiting the leaching of the nitratenitrogen to the deep TDR probe would be the well developed argillic horizon typical of the Crete silt loam soil series. This horizon tends to limit the infiltration of solutes to the $0.9-\mathrm{m}$ depth.
There were no significant correlations between $\theta_{\mathrm{v}}$ and $\mathrm{EC}_{\mathrm{a}}$ for any Experiment 2 treatments regardless of EMI orientation or TDR probe depth (Table 4). At the start of the measurement period, surface $\theta_{\mathrm{v}}$ was lowest for the $\mathrm{Cv}$ treatments (Fig. 6). After cover-crop destruction, surface $\theta_{\mathrm{v}}$ for the $\mathrm{Cv}$ treatments increased until the field was planted with corn. Following plant emergence, the surface $\theta_{\mathrm{v}}$ decreased slightly until the crop reached approximately $30-\mathrm{cm}$ height. When the crop reached $30 \mathrm{~cm}$, all treatments $\theta_{\mathrm{v}}$ rapidly decreased to approximately $0.12 \mathrm{~m}^{3} \mathrm{~m}^{-3}$. The surface $\theta_{\mathrm{v}}$ cycled up and down between 0.12 and 0.30 from approximately day 170 to day 210 because of precipitation and scheduled irrigations (Fig. 6). Relatively frequent cycling of the surface $\theta_{\mathrm{v}}$ throughout the season for Experiment 2 did not correlate with the EC patterns measured by EMI, regardless of the dipole orientation (Table 4 and Fig. 6). Also, the relatively stable deep $\theta_{\mathrm{v}}$ did not correlate with the pattern from either EMI dipole orientation (Table 4 and Fig. 6).

\section{Conclusions}

Results from this study indicate the seasonal soilcrop EC dynamics of an irrigated, manure amended corn silage field measured by EMI are primarily driven by surface $(<0.2 \mathrm{~m})$ changes as opposed to deeper $(>0.9 \mathrm{~m})$ changes. There were no significant correlations measured between $\mathrm{EC}_{\mathrm{a}}$ and $\theta_{\mathrm{v}}$ for any treatment, depth 
Journal of Environmental and Engineering Geophysics
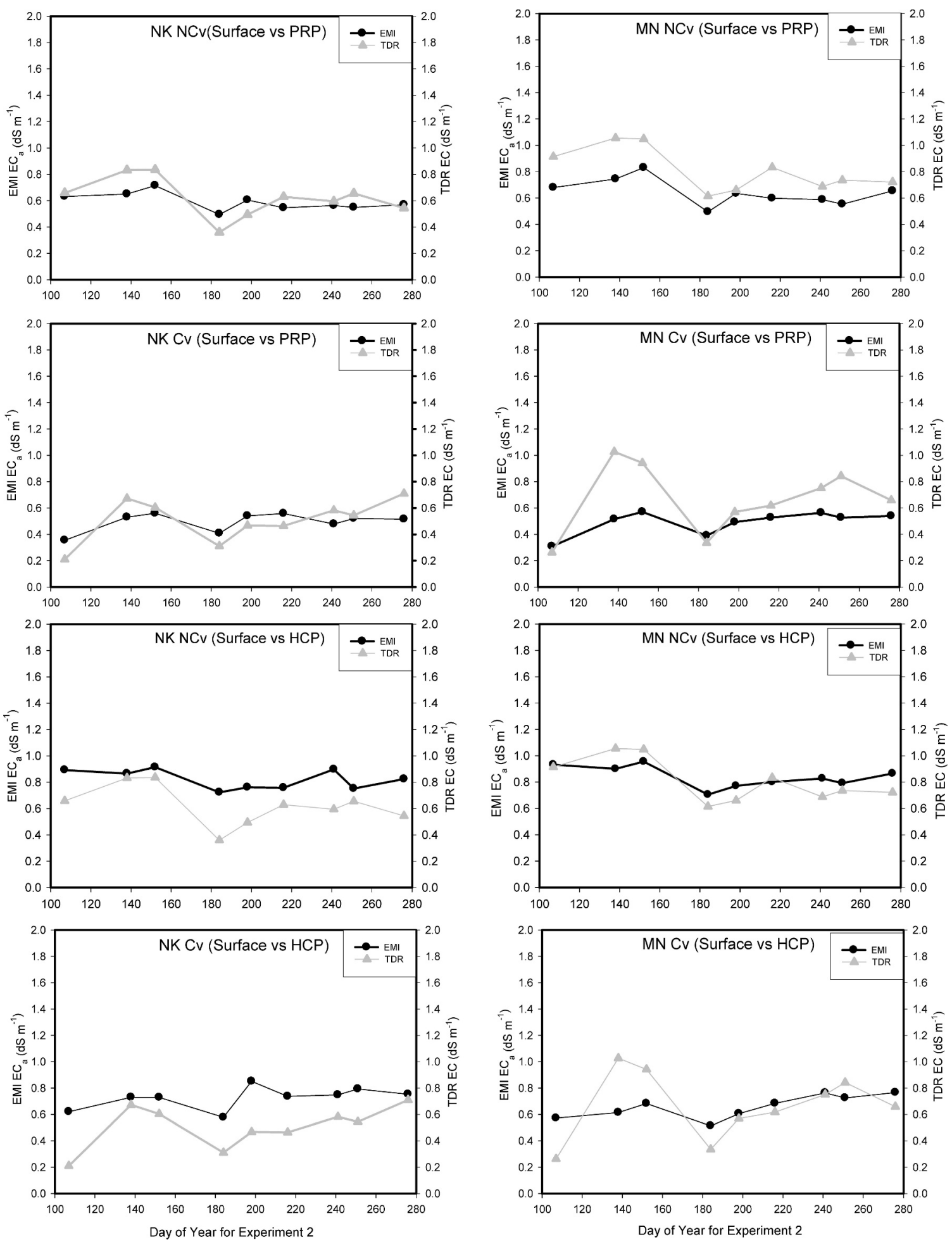

Figure 4. Apparent soil electrical conductivity as measured by electromagnetic induction (EMI) and surface soil electrical conductivity as measured by time-domain reflectometry (TDR) for manure (MN)and commercial fertilizer (NK) at the nitrogen rate for a corn silage crop, with a winter cover-crop (Cv) and no-cover crop (NCv) treatment for Experiment 2. Note PRP and HCP refer to the perdendicular and horizontal co-planar coil orientation, respectively, of the DualEM-1S. 
Woodbury et al.: Dynamic Depth Response from TDR
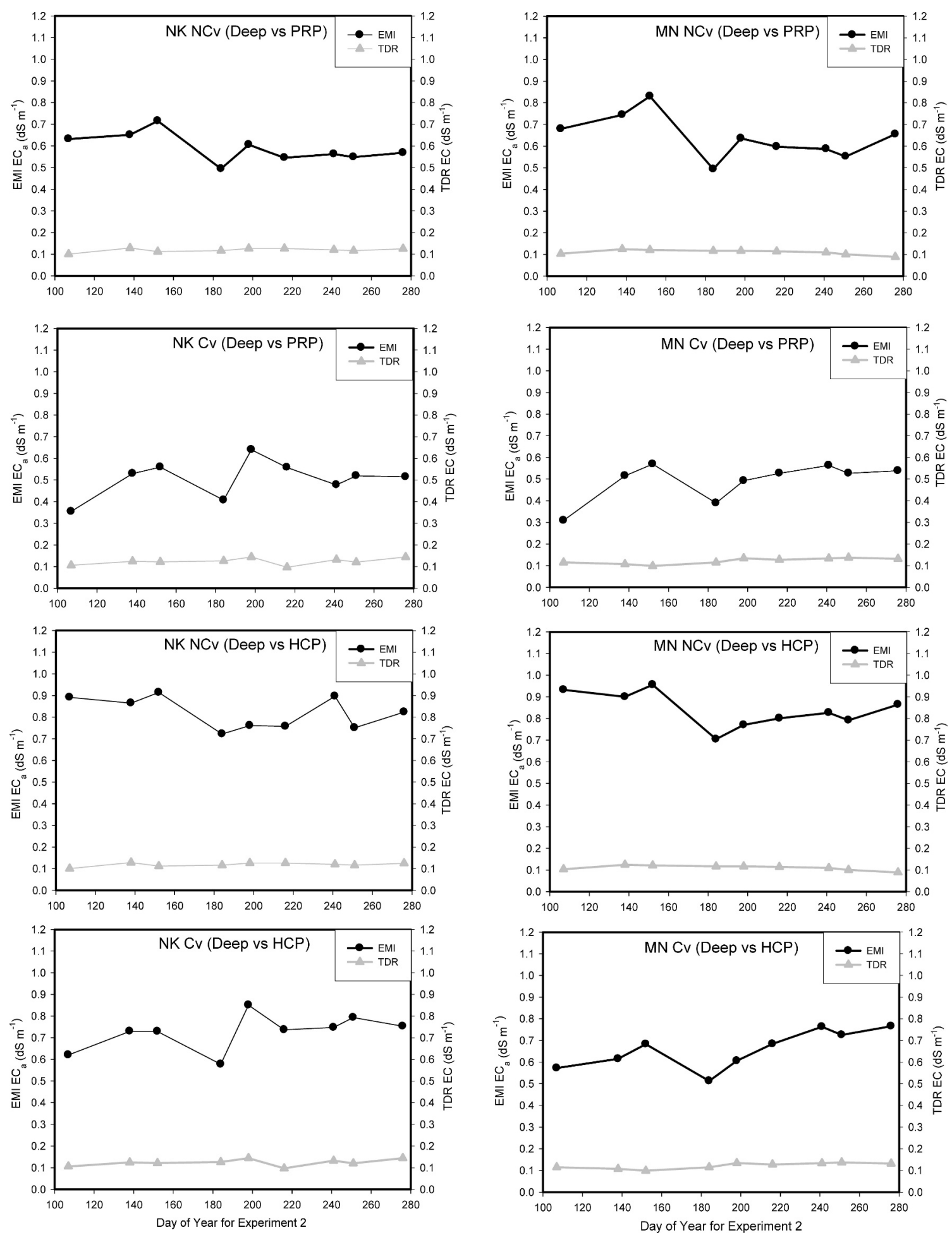

Figure 5. Apparent soil electrical conductivity as measured by electromagnetic induction (EMI) and deep (0.9 m) soil electrical conductivity as measured by time-domain reflectometry (TDR) for manure (MN) and commercial fertilizer (NK) at the nitrogen rate for a corn silage crop, with a winter cover-crop (Cv) and no-cover crop (NCv) treatment for Experiment 2. Note PRP and HCP refer to the perdendicular and horizontal co-planar coil orientation, respectively, of the DualEM-1S. 
Journal of Environmental and Engineering Geophysics

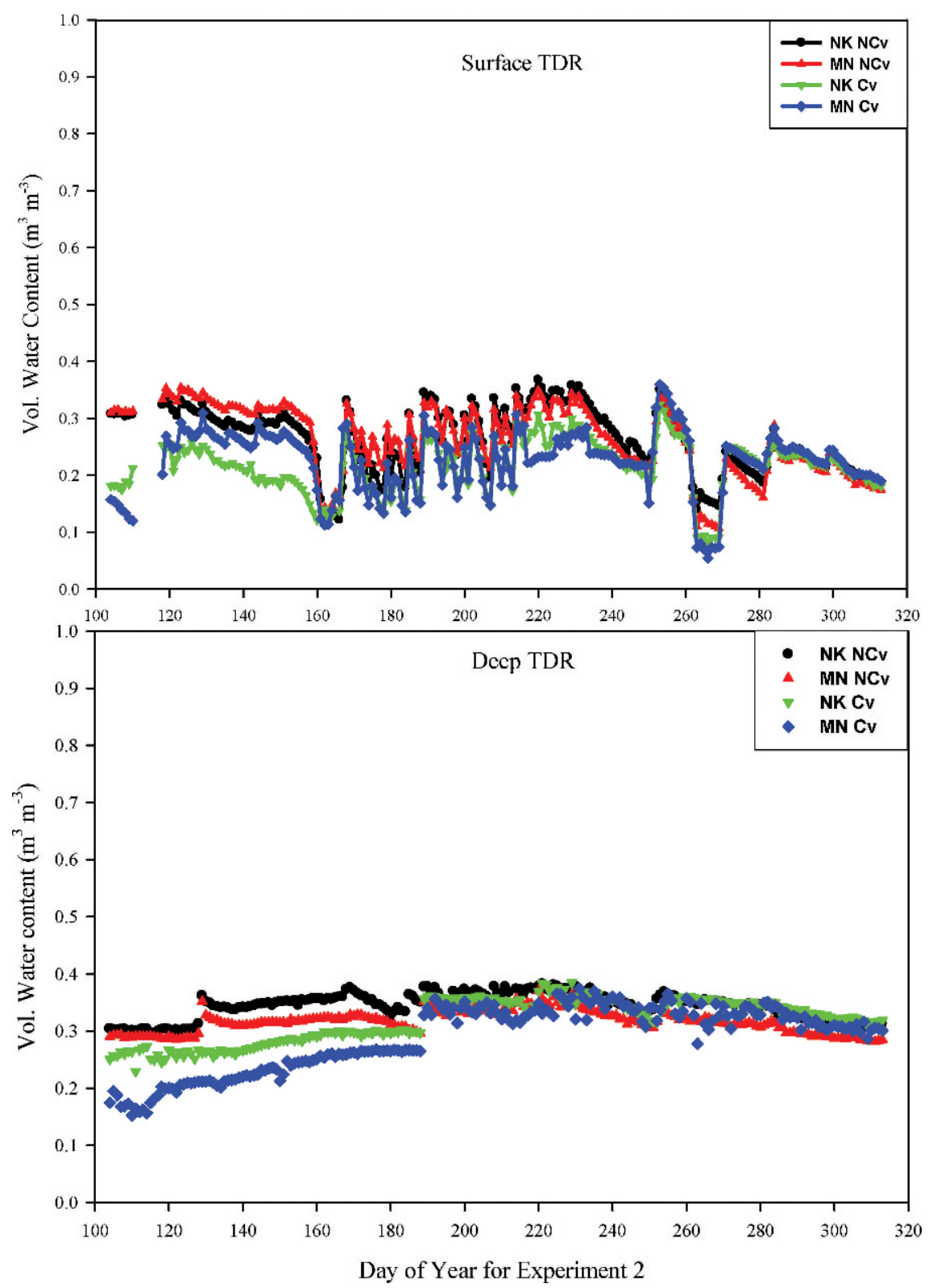

Figure 6. Time-domain reflectometry (TDR) volumetric water content for surface (vertical probe orientation measuring 0.05-0.2 m depth) and deep (horizontal probe orientation measuring $0.9 \mathrm{~m}$ depth) for a field fertilized with commercial fertilizer (NK) and manure (MN) at an agronomic rate for growing a corn silage crop with a winter cover-crop (Cv) and no-cover crop (NCv) treatment for Experiment 2.

or dipole orientation. The changes measured by EMI appear to be driven by surface ionic changes resulting from crop interactions and not soil volumetric water content.

Seasonal soil-crop EC dynamics measured by TDR and EMI were significantly $(P<0.05)$ correlated for all surface measures. Significant correlations were detected between surface $\mathrm{EC}_{\mathrm{TDR}}$ and $\mathrm{EMI}$ values for all treatments except NK-NCv. There were no significant correlations between deep $\mathrm{EC}_{\mathrm{TDR}}$ and either PRP or HCP orientations for the EMI.

Surface EC variations impact the values measured by both PRP and HCP orientations; however, the PRP value is affected to a greater extent than HCP because of the depth response curve characteristics for each orientation. The PRP orientation has a greater portion of the depth response curve near the surface; this results in a centroid of measure that is half the $\mathrm{HCP}$ 


\section{Woodbury et al.: Dynamic Depth Response from TDR}

orientation. Therefore, seasonal changes measured by TDR probes near the surface are expected to correlate much more strongly with EMI's PRP orientation than the HCP orientation.

The ability to non-intrusively measure nutrient mineralization and crop uptake throughout the growing season provides researchers with a powerful tool for understanding soil-crop interactions. Monitoring the soil-crop dynamic throughout the season will facilitate development of management practices for amending soil with manure while protecting the environment from unintended contamination.

\section{References}

Chee-Sanford, J.C., Mackie, R.I., Koike, S., Krapac, I.G., Lin, Y., Yannarell, A.C., Maxwell, S., and Aminov, R.I., 2009, Fate and transport of anitbiotic residues and antibiotic resistance genes following land application manure waste: Journal of Environmental Quality, 38, 1086-1108.

Cockx, L., Van Meirvenne, M., Vitharana, U.W.A., Verbeke, L.P.C., Simpson, D., Saey, T., and Van Coillie, F.M.B., 2009, Extracting topsoil information from EM38DD sensor data using a neural network approach: Soil Science Society of America Journal, 73, 1-8.

Dalton, F.N., 1992, Development of TDR for measuring soil water content and bulk EC: in ASA Monograph advances in measurement of soil physical properties: Bringing theory into practice: Soil Science Society of America Special Publication, 30, 143-167.

Dalton, F.N., Herkelrath, W.N., Rawlins, D.S., and Rhoades, J.D., 1984, Time domain reflectometry: Simultaneous measurement of soil water content and electrical conductivity with a single probe: Science, 224, 989990.

Das, B.S., Wraith, J.M., and Inskeep, W.P., 1999, Nitrate concentration in the root zone estimated using time domain reflectometry: Soil Science Society of America Journal, 63, 1561-1570.

Dordas, C.A., Lithourgidis, A.S., Matsi, T., and Barbayiannis, N., 2008, Application of liquid cattle manure and inorganic fertilizers affect dry matter, nitrogen accumulation, and pertitioning in maize: Nutrient Cycling in Agroecosystems, 80, 283-296.

Eigenberg, R.A., Doran, J.W., Nienaber, J.A., Ferguson, R.B., and Woodbury, B.L., 2002, Electrical conductivity monitoring of soil condition and available $\mathrm{N}$ with animal manure and a cover crop: Agriculture, Ecosystems and Environment, 88, 183-193.

Eigenberg, R.A., Nienaber, J.A., Woodbury, B.L., and Ferguson, R.B., 2003, Crop and soil status as indicated by electrical conductivity surveys of a field with cover crop and manure amendments: ASAE Paper 032338, St. Joseph, Michigan.

Eigenberg, R.A., Nienaber, J.A., Woodbury, B.L., and Ferguson, R., 2006, Soil conductivity as a measure of soil and crop status - a four year summary: Soil Science Society of America Journal, 70, 1600-1611.

Eigenberg, R.A., Lesch, S.M., Woodbury, B., and Nienaber, J.A., 2008, Geospatial methods for monitoring a vegetative treatment area receiving beef feedlot runoff: Journal of Environmental Quality, 37(5, Supplement) S68-S77.

Ferguson, R.B., Nienaber, J.A., Eigenberg, R.A., and Woodbury, B.L., 2005, Long-term effects of sustained beef feedlot manure application on soil nutrients, corn silage yield, and nutrient uptake: Journal of Environmental Quality, 34, 1672-1681.

Giese, K., and Tiemann, R., 1975, Determination of the complex permittivity from thin-sample time domain reflectometry, improved analysis of the step response waveform: Advances in Molecular Relaxation Processes, 7, 45-49.

Gilley, J.E., Sabatka, W.F., Eghball, B., and Marx, D.B., 2008, Nutrient transport as affected by rate of overland flow: Transactions of ASABE, 51(4) 1287-1293.

Griffin, T.S., Honeycutt, C.W., and He, Z., 2002, Effects of temperature, soil water status, and soil type on swine slurry nitrogen transformations: Biology and Fertility of Soils, 36, 442-446.

Griffin, T.S., Honeycutt, C.W., Albrecht, S.L., Sistani, K.R., Torbert III., H.A., Wienhold, B.J., Woodbury, B.L., Hubbard, R.K., and Powell, J.M., 2008, Nationally coordinated evaluation of soil nitrogen mineralization rate using a standardized aerobic incubation protocol: Communications in Soil Science and Plant Analysis, 39(1-2) 257-268.

Hanselman, T.A., Graetz, D.A., and Wilkie, A.C., 2003, Manure-borne estrogens as potential environental contaminants: a review: Environmental Science and Technology, 37(24) 5471-5478.

Hepperly, P., Lotter, D., Ulsh, C.Z., Seidel, R., and Reider, C., 2009, Compost, manure and synthetic fertilizer influences crop yields, soil properties, nitrate leaching and crop nutrient content: Compost Science \& Utilization, 17(2) 117-126.

Honeycutt, C.W., Griffin, T.S., Wienhold, B.J., Eghball, B., Albrecht, S.L., Powell, J.M., Woodbury, B.L., Sistani, K.R., Hubbard, R.K., Torbert III., H.A., Eigenberg, R.A., Wright, R.J., Jawson, M.D., and Zhongqi, H., 2005, Protocols for nationally coordinated laboratory and field research on manure nitrogen mineralization: Communications in Soil Science and Plant Analysis, 36, 2807-2822.

Hubbard, R.K., Bosch, D.D., Marshall, L.K., Strickland, T.C., Rowland, D., Griffin, T., Honeycutt, C.W., Albrecht, S., Sistani, K., Torbert III., H.A., Woodbury, B.L., Powell, J.M., and Wienhold, B.J., 2008, Nitrogen mineralization from broiler litter applied to Southeastern coastal plain soils: Journal of Soil and Water Conservation, 63(4) 182-192.

Johnson, C.K., Eigenberg, R.A., Doran, J.W., Wienhold, B.J., Eghball, B., and Woodbury, B.L., 2005, Status of soil electrical conductivity studies by Central state researchers: Transactions of the ASAE, 48(3) 979-989. 
Journal of Environmental and Engineering Geophysics

Khan, S.J., Roser, D.J., Davies, C.M., Peters, G.M., Stuetz, R.M., Tucker, R., and Ashbolt, N.J., 2007, Chemical contaminants in feedlot wastes: Concentrations, effects and attenuation. Environmental International, 34, 839-859.

Martinez, G., Vanderlinden, K., Ordonez, R., and Muriel, J.L., 2009, Can apparent electrical conductivity improve the spatial characterization of soil organic carbon?: Vadose Zone Journal, 8, 586-593.

McDowell, R., and Sharpley, A., 2002, Phosphorus transport in overland flow in response to position of manure application: Journal of Environmental Quality, 31, 217-227.

McKenzie, R.C., Chomistek, W., and Clark, N.F., 1989, Coversion of electromagnetic induction reading to saturated paste extract values in soils for different temperature, texture and moisture conditions: Canadian Journal of Soil Science, 69, 25-32.

Nissen, H.H., Moldrup, P., and Henriksen, K., 1998, Time domain reflectometry measurements of nitrate transport in manure-amended soil: Soil Science Society of America Journal, 62, 99-109.

Nyiraneza, J., Chantigny, M.H., N'Dayegamiye, A., and Laverdiere, M.R., 2009, Dairy cattle manure improves soil productivity in low residue rotation systems: Agronomy Journal, 101, 207-214.
Robinson, D.A., Abdu, H., Jones, S.B., Seyfried, M., Lebron, I., and Knight, R., 2008, Eco-geophysical imaging of watershed-scale soil patterns links with plant community spatial patterns: Vadose Zone Journal, 7, 1132-1138.

Topp, G.C., Davis, J.L., and Annan, A.P., 1980, Electromagnetic determination of soil water content: measurement in coaxial transmission lines: Water Resources Research, 16, 574-582.

USEPA, 2003, National pollutant discharge elimination system permit regulation and effluent limitation guidelines and standards for concentrated animal feeding operations (CAFOs): Federal Register, 69(29) 71767274.

Watts, D.B., Torbert, H.A., and Prior, S.A., 2007, Mineralization of nitrogen in soils amended with dairy manure as affected by wetting/drying cycles: Communications in Soil Science and Plant Analysis, 38, 2103-2116.

Woodbury, B.L., Lesch, S.M., Eigenberg, R.A., Miller, D.N., and Spiehs, M.J., 2009, Electromagnetic induction sensor data to identify areas of manure accumulation on a feedlot surface: Soil Science Society of America Journal, 73(6) 2068-2077.

Wortmann, C.S., and Walters, D.T., 2006, Phosphorus runoff during four years following composted manure application: Journal of Environmental Quality, 35, 651-657. 